Technical paper

\title{
Effect of Drying Parameters on Physiochemical and Sensory Properties of Fruit Powders Processed by PGSS-, Vacuum- and Spray-drying
}

\author{
Urban Feguš, ${ }^{1, *}$ Uroš Žigon, ${ }^{1}$ Marcus Petermann ${ }^{2}$ and Željko Knez ${ }^{3}$ \\ ${ }^{1}$ Etol, d.d.; Škofja vas 39; SI-3211Škofja vas, Slovenia; +386 (0)3 4277130 \\ ${ }^{2}$ Ruhr University Bochum; Institute of Particle Technology; Universitätsstr. 150; 44780 Bochum; Germany \\ ${ }^{3}$ University of Maribor; Faculty of chemistry and chemical technology; Laboratory of separation processes \\ and product design; Smetanova ul. 17; 2000 Maribor; Slovenia \\ * Corresponding author: E-mail: urban.fegus@gmail.com
}

Received: 03-09-2014

\begin{abstract}
Aim of this experimental work was to investigate the possibility of producing fruit powders without employing drying aid and to investigate the effect of drying temperature on the final powder characteristics. Raw fruit materials (banana puree, strawberry puree and blueberry concentrate) were processed using three different drying techniques each operating at different temperature conditions: vacuum-drying $\left(-27-17{ }^{\circ} \mathrm{C}\right)$, spray-drying $\left(130-160{ }^{\circ} \mathrm{C}\right)$ and PGSS-drying $\left(112-152{ }^{\circ} \mathrm{C}\right)$. Moisture content, total colour difference, antioxidant activity and sensory characteristics of the processed fruit powders were analysed. The results obtained from the experimental work indicate that investigated fruit powders without or with minimal addition of maltodextrin can be produced. Additionally, it was observed that an increase in process temperature results in a higher loss of colour, reduced antioxidant activity and intensity of the flavour profile.
\end{abstract}

Keywords: PGSS-drying; Vacuum-drying; Spray-drying; Sensory evaluation, Fruit powders

\section{Introduction}

Fruits are valuable source of vitamins and minerals and are present in variety of food applications in order to provide balanced and nutritious diet. However, fresh fruits are composed mostly out of water and therefore are considered as highly perishable materials and prone to different microbial contamination. Most of the enzymes affecting fruits such as amylases, phenoloxidases and peroxidases are inhibited at low moisture content, but their activity is quickly increased with the moisture content. Chemical changes, which affect food quality, are mainly related to non-enzymatic browning. ${ }^{1}$ Depending on the product, different mechanisms of deterioration will occur at different water activity values, and in order to overcome shelf-life problems water activity level must be reduced. ${ }^{2}$ This can be achieved by drying. 3.4

Spray drying is a widely used method for dehydrating fruits. The process is based on transforming the spray of liquid feed, such as juices, slurries and purees, by expo- sing it to a hot stream of air in order to obtain dry powders or agglomerates. ${ }^{5}$ The whole process of drying is carried out in a spray dryer and consists of three main stages: atomization, evaporation of water and separation of dried particles from humid air. ${ }^{6,7}$ Firstly, drying air must be heated to an appropriate temperature and cleaned in order to avoid contamination of the product by dust from outside air. Afterwards, the fruit concentrate is pumped through an atomizer in order to produce a fine mist, which is exposed to hot air in the drying chamber, and rapid evaporation of water takes place. After the drying stage, powdered product is removed from the drying chamber into a storage container while the air is removed through a cyclone into the atmosphere. ${ }^{3}$

Spray-drying fruit concentrates is problematic because of the sticky behaviour of fruit powders due to low glass transition temperature of monosaccharides and disaccharides which are present in high concentration. ${ }^{8,9,10}$ During drying, fruits are exposed to elevated temperature and when temperature inside fruits rise above glass transi- 
tion temperature $\left(T_{g}\right.$ physical changes, including thermal expansion, increase of specific heat and decrease of viscosity, appear causing material to stick on the walls of dryer or even collapse. ${ }^{11}$ In general, the higher the temperature above $T_{g}$ the higher the degree of stickiness will appear. Stickiness can be avoided by increasing the overall $T_{g}$ of the system by adding different carrier materials or so-called drying aids such as maltodextrins with different dextrose equivalents (DE) (Table 1). ${ }^{9}$

Table 1. - Glass transition temperature of different carbohydrates

\begin{tabular}{lcc}
\hline Material & $\begin{array}{c}\text { Molecular } \\
\text { weight } \\
{[\mathbf{g} / \mathbf{m o l}]}\end{array}$ & $\begin{array}{c}\text { Glass transition } \\
\text { temperature } \\
{\left[{ }^{\circ} \mathbf{C}\right]}\end{array}$ \\
\hline Fructose & 180 & 5 \\
Glucose & 180 & 31 \\
Sucrose & 342 & 62 \\
Maltodextrin DE 10 & 1800 & 160 \\
Maltodextrin DE 20 & 900 & 141 \\
Maltodextrin DE 36 & 500 & 100 \\
\hline
\end{tabular}

Spray drying at elevated temperatures enhances loss of volatile flavouring compounds, discoloration, loss of texture and caramelization. In order to avoid this physical and structural changes alternative drying methods such as freeze-drying or PGSS-drying can be applied.

Freeze-drying is another widely used process for dehydration of foodstuffs where water is removed under reduced pressure and sub-zero temperatures by sublimation. Being a low temperature process, it is especially useful for drying heat sensitive materials which cannot be exposed to elevated temperature. ${ }^{4}$ Advantage of these mild drying conditions is high degree of preservation of dried fruits (colour, flavour and antioxidant content). Additionally, drying at sub-zero temperatures also inhibits most of microbial reactions, even enzymatic browning. However in order to retain desired final product properties the temperature of frozen part must be kept under melting point $\left(T_{m}\right)$ and $T_{g}$. If the temperature is held between $T_{m}$ and $T_{g}$ the material may collapse when all of the ice sublime. Below $T_{g}$ material maintains high viscosity and thus shrinking and consequently collapse of the particles is prevented. The main disadvantages of the process are high overall operational costs due to slow drying rate and maintenance of low pressure value during processing. ${ }^{1,12}$

Unlike both convective drying processes, PGSS-drying is using solvent power of the supercritical carbon dioxide $\left(\mathrm{SC}-\mathrm{CO}_{2}\right)$ to remove water. ${ }^{13}$ The technique is based on saturating aqueous solution with $\mathrm{SC}-\mathrm{CO}_{2}$. The saturation is accomplished by mixing the solution to be dried with compressed and preheated carbon dioxide in the static mixer. Afterwards the gas-saturated solution is depressurized through a nozzle into the precipitation chamber operating at atmospheric pressure. During the expansion, water is evaporated together with the carbon dioxide and micro-metre range particles are obtained within a second due to the intense cooling effect caused by Joule-Thompson phenomena. ${ }^{14,15}$ An advantage of the PGSS-drying process is that it allows drying at lower temperatures and thus reduces thermal degradation of the heat-sensitive materials to be dried. The only part operating at higher temperature is the static mixer. Additionally, drying process is carried-out in oxygen-free and inert atmosphere of the carbon dioxide and therefore is less possibility for the microbiological contamination of the final product. ${ }^{16}$

The aim of presented experiments was to investigate feasibility of drying fruit preparations by using PGSS drying and vacuum belt drying method in order to obtain pure banana, blueberry and strawberry powder. Afterwards the effect of drying temperature on physical and chemical characteristics (final water content, total colour difference and antioxidant activity) and sensory properties (typicality and intensity) of the processed fruit powders was studied. Finally, results were compared to fruit powders produced by the conventional spray drying method.

\section{Materials and Methods}

\section{1. Sample Preparation}

For drying experiments fruit preparations (banana, strawberry and blueberry) composed out of fruit puree and/or concentrate were used. Banana was prepared by mixing banana puree $\left({ }^{\circ} \mathrm{Bx}=22 \pm 2\right)$, Tropicalia, Netherlands) and banana concentrate $\left({ }^{\circ} \mathrm{Bx}=70 \pm 1\right.$, Tropicalia) in the ratio $4: 1$. Strawberry puree was prepared by mixing strawberry puree $\left({ }^{\circ} \mathrm{Bx}=7 \pm 2\right.$, Iberfruta) and strawberry concentrate $\left({ }^{\circ} \mathrm{Bx}=65 \pm 1\right.$, Beerenfrost $)$ in the ratio $4: 1$. Blueberry powder was obtained by using blueberry concentrate $\left({ }^{\circ} \mathrm{Bx}=65 \pm 1\right.$, Flagfood). The same composition of fruit preparations was used for all drying experiments. As a drying aid maltodextrin with $15 \mathrm{DE}$ was used (Cargill).

\section{2. Drying Methods}

Before drying, fruit components were thawed at $4{ }^{\circ} \mathrm{C}$ and mixed in predefined ratio. Afterwards fruit preparation were placed into double-walled vessel were pasteurization took place. Fruit preparation were brought up to the $\mathrm{T}=83{ }^{\circ} \mathrm{C}$ and left for 20 minutes during mixing. Afterwards mixture was cooled down to a room temperature and dried according to the procedure described in the following sections.

\section{2. 1. Spray Drying}

Spray drying experiments were performed in a cocurrent spray dryer equipped with rotary atomizer. Drying 
air was cleaned through a filter and introduced into a drying chamber. Prepared fruit concentrate was placed into a vessel, where maltodextrin and water were added during mixing. Composition of the initial feed is given in the following table.

Table 2. - Feed composition for spray drying experiments

\begin{tabular}{lccc}
\hline & $\begin{array}{c}\text { Fruit preparation } \\
{[\%]}\end{array}$ & $\begin{array}{c}\text { Maltodextrin } \\
{[\%]}\end{array}$ & $\begin{array}{c}\text { Water } \\
{[\%]}\end{array}$ \\
\hline Banana & 32,3 & 22,5 & 45,2 \\
Blueberry & 22,7 & 22,1 & 55,2 \\
Strawberry & 47,1 & 17,6 & 35,3 \\
\hline
\end{tabular}

Initial feed was pumped through the atomizer into a drying chamber. After drying stage, dried product was collected at the bottom of the drying chamber. The final product was sieved and packed in aluminium bag (Figure 1).

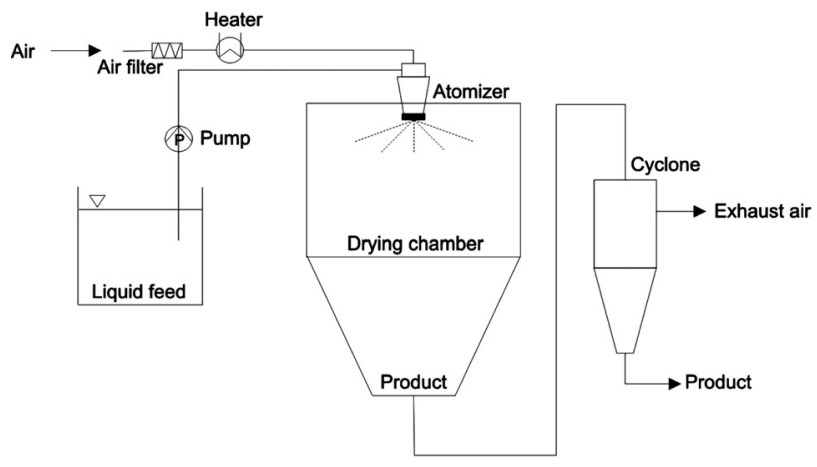

Figure 1. - Spray drying process

Process parameters were kept constant for all fruit concentrates and are presented in Table 3.

Table 3. - Spray drying process parameters

\begin{tabular}{lcccc}
\hline $\boldsymbol{T}_{\text {Feed }}$ & $\begin{array}{c}\boldsymbol{T}_{\text {in }} \\
{\left[{ }^{\circ} \mathbf{C}\right]}\end{array}$ & $\boldsymbol{T}_{\text {out }}$ & $\begin{array}{c}\dot{\boldsymbol{m}}_{\text {air }} \\
{\left[\mathbf{m}^{\mathbf{3}} / \mathbf{h}\right]}\end{array}$ & $\begin{array}{c}\boldsymbol{\omega}_{\text {Wheel }} \\
{[\mathbf{r p m}]}\end{array}$ \\
\hline 25 & $130-160$ & 90 & 6200 & 17.500 \\
\hline
\end{tabular}

\section{2. 2. Vacuum Drying}

For drying under sub-atmospheric pressure two procedures were used: liquid freeze- and vacuum- drying. Fruit concentrates were placed in a vessel and applied through the dosing system on the conveyor into the drying chamber operating at low pressure. Dried fruit powders were broken into smaller particles by crusher, sieved and packed into aluminium bags (Figure 2 ).

Temperature of the heating plates and the velocity of the conveying belt were adjustable. Process parameters for vacuum drying experiment are presented in Table 4.

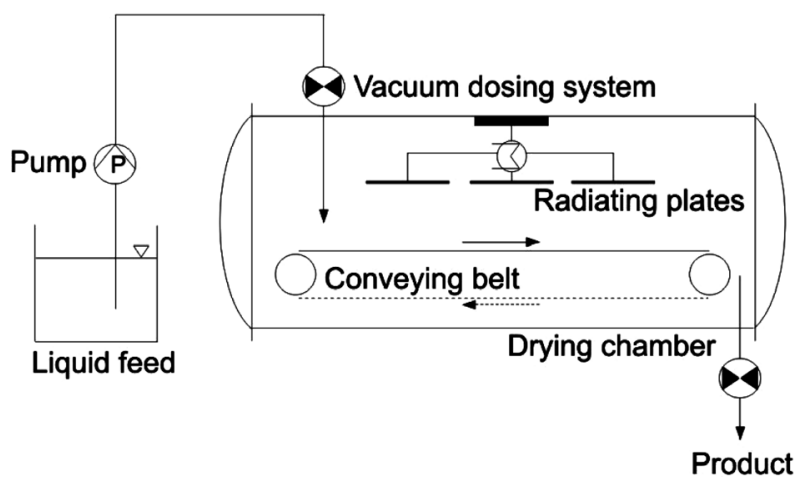

Figure 2. - Vacuum drying process

Table 4. - Vacuum drying parameters

\begin{tabular}{lccc}
\hline $\boldsymbol{T}_{\text {Feed }}$ & $\begin{array}{c}\boldsymbol{T}_{\text {condensator }} \\
{\left[{ }^{\circ} \mathbf{C}\right]}\end{array}$ & $\boldsymbol{T}_{\text {sublimation }}$ & $\begin{array}{c}\mathbf{P} \\
{[\mathbf{m b a r}]}\end{array}$ \\
\hline 25 & -50 & $-27-17,5$ & $0,5-20$ \\
\hline
\end{tabular}

\section{2. 3. PGSS Drying}

Carbon dioxide was brought to supercritical state by pressurizing and heating using heat exchanger. Afterwards $\mathrm{SC}-\mathrm{CO}_{2}$ was pumped through the nozzle in to order achieve desirable temperature inside spray tower. Afterwards liquid feed was delivered to the static mixer where SC$\mathrm{CO}_{2}$ and fruit concentrate were intensively mixed at elevated temperature and pressure. Mixture was expanded through the pressure nozzle into the drying chamber and final particles were obtained at the bottom of the drying chamber. Carbon dioxide was removed together with evaporated water through the upper part of drying chamber (Figure 3). Drying parameters are presented in Table 5.

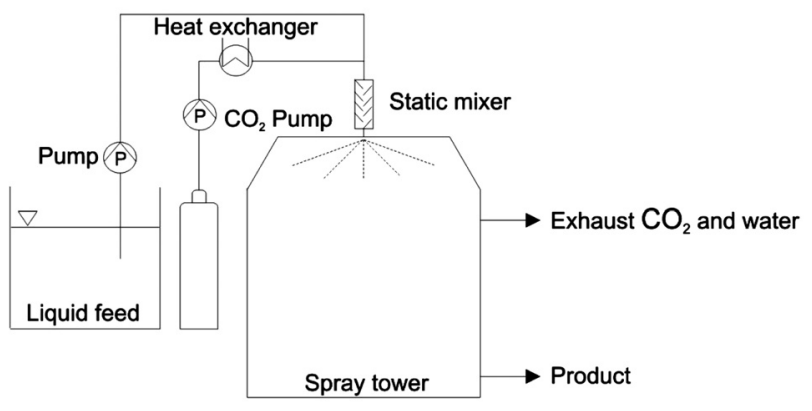

Figure 3. - PGSS drying process

Table 5. - PGSS drying parameters

\begin{tabular}{lcccc}
\hline $\boldsymbol{T}_{\text {Feed }}$ & $\begin{array}{c}\boldsymbol{T}_{\text {Mix }} \\
{\left[{ }^{\circ} \mathbf{C}\right]}\end{array}$ & $\boldsymbol{T}_{\text {Tower }}$ & $\dot{\boldsymbol{m}}_{\mathrm{CO} 2} \dot{\boldsymbol{m}}_{\text {Feed }}$ \\
\hline 25 & $112-152$ & $32-64$ & $80-110$ & $1,5-2,2$ \\
\hline
\end{tabular}




\section{3. Analytical Methods}

\section{3. 1. Composition of Fruit Concentrates}

Composition of the fruit concentrates was determined using Varian »Pro Star« HPLC equipped with RI detector. For separation of sugars Supelcosil LC-NH2 $(25 \mathrm{~cm}$ $\times 4,6 \mathrm{~cm}, 5 \mu \mathrm{m})$ was used. Column temperature was maintained at $30{ }^{\circ} \mathrm{C}$. Samples were dissolved in $25 \mathrm{~mL}$ mixture of acetonitrile (99,9\%, Sigma Aldrich) and deionized water in the ratio $3: 1$ by vigorous shaking followed by sonification (5min.). Afterwards samples were filtered using syringe filters (Chromafil ${ }^{\circledR}$ Xtra) and $20 \mu$ of sample was injected into the loop. For quantification and calibration a standard solutions were prepared by dissolving fructose $(99,5 \%$, Tate\&Lyle) glucose $(99,5 \%$, Tate\&Lyle) and sucrose $(99,9 \%$, Sladorana) in the mobile phase for five different concentration levels in order to obtain calibration curve. Afterwards quantification was performed by comparing the responses. Quantification results of sugars (fructose, glucose and fructose) are presented in Table 2.

Table 6. - Sugar composition of fruit purees and concentrates

\begin{tabular}{lcccr}
\hline $\begin{array}{l}\text { Fruit } \\
\text { concentrate }\end{array}$ & $\begin{array}{c}\text { Total solid } \\
\text { content } \\
{\left[{ }^{\circ} \mathbf{B x} \text { ] }\right.}\end{array}$ & $\begin{array}{c}\text { Fructose } \\
\text { [g/100g dry matter] }\end{array}$ \\
\hline Banana puree & 31 & 28,8 & 32,0 & 20,4 \\
Strawberry puree & 18 & 28,9 & 29,4 & 3,4 \\
Blueberry concentrate & 65 & 36,3 & 33,5 & 0,1 \\
\hline
\end{tabular}

\section{3. 2. Water Content}

Free water content in the powdered samples was determined by water activity meter and total water content was determined using Karl-Fischer titration according to the ISO 760:1978.

\section{3. 3. Total Colour Difference}

Total colour difference of fruit powders processed by alternative methods (vacuum drying and PGSS drying) was compared to spray-dried products using Konica Minolta CM-3500d spectrophotometer. The results are expressed as Hunter colour values: $\mathrm{L}^{*}$-value measures the lightness of the sample, $a^{*}$ value measures the red and green colour hue while $b^{*}$ value is used for determination of yellow and blue colour hue. The total colour difference was calculated using equation 1.

$$
\Delta E=\sqrt{\left(L_{0}^{*}-L^{*}\right)^{2}+\left(a_{0}^{*}-a^{*}\right)^{2}+\left(b_{0}^{*}-b^{*}\right)^{2}}
$$

$E$ total colour difference

$L_{0}^{*}$ lightness value of the reference sample

$L^{*}$ lightness value of the analysed sample

$a_{0}^{*}$ redness and greenness value of the reference sample $a^{*}$ redness and greenness value of the analysed sample

$b_{0}^{*} \quad$ yellowness and blueness value of the reference sample

$b^{*}$ yellowness and blueness of the analysed sample

\section{3. 4. Antioxidant Activity}

Antioxidant activity was determined using ACW method (Antioxidant activity in water soluble compounds) according to the procedure described in the article with minor modifications. ${ }^{17}$ As reference sample ascorbic acids was used. Results for determination of antioxidant activity are expressed as $\mathrm{mg}$ of ascorbic acid per $\mathrm{g}$ of sample.

\section{4. Sensory Evaluation}

Sensory evaluation of fruits powders processed by different drying techniques was performed by experienced panel trained according to ISO 5496:2006. Sensory panel consists of 14 assessors who were familiar with the utilized methods. Samples for sensory evaluation were presented as instant drinks application containing 1,5\% of dry matter derived from fruit. Afterwards fruit powders were reconstituted in water, mixed, distributed into labelled plastic caps and directly introduced to assessors in random order. Afterwards data was collected and results were generated using Addinsoft XLSTAT software.

Ranking method was applied according to ISO 8587:2006 for sensory evaluation of banana and blueberry powders. Assessors were asked to rank samples based on two different key attributes, intensity and typicality.

Possible significant difference between the samples was calculated using Friedman's statistic method with equation 2.

$$
F_{\text {test }}=\frac{12}{j \times p(p+1)}\left(R_{1}^{2}+\cdots+R_{p}^{2}\right)-3 j(p+1)
$$

In case the obtained Friedman's test results confirmed statistical insignificant difference between the samples $\left(\mathrm{F}_{\text {test }}\right.$ value is equal or greater than threshold value), LSD test (equation 3) was used to highlight the pairs of samples which were statistically different at chosen risk of $\alpha=0,05$.

$$
L S D=1,96 \times \sqrt{\frac{j \times p(p+1)}{6}}
$$

$\mathrm{R}_{\mathrm{i}}$ the rank sum of product $i$

$\mathrm{p}$ is the number of products ranked

$\mathrm{j}$ is the number of assessors

In case of strawberry, a triangle test was performed according to ISO 4120:2004. Samples were presented to 
assessors in triads (two samples were alike and one differ from others). Assessors were asked to indicate which one is different, even if the selection was based only on a guess.

\section{Results and Discussion}

\section{1. Processing of the Materials}

Fruit purees and concentrates were successfully processed by spray-drying, but it was necessary to use maltodextrin as carrier material because of the high operating temperatures (up to $160{ }^{\circ} \mathrm{C}$ ) and low $T_{g}$ of the raw materials. $T_{g}$ values of sugars are much lower than operating temperature inside the spray tower and the only way to overcome the problem of stickiness is by adding maltodextrin. ${ }^{18,19,20}$

Without maltodextrin only banana powder was obtained by freeze drying. In case of strawberry the moisture content of the initial feed was too high, meaning that not sufficient time was available for drying. In case of blueberry the concentration of sugars was too high and thus material was affected by the glass transition temperature. Both materials were successfully processed with addition of $20 \mathrm{wt}$. \% of maltodextrin. Similar observation were made by Mosquera et. al. The addition of maltodextrin was required to improve the stability of the borojo fruit powders. $^{21}$

Using PGSS drying method, only banana powder was successfully processed. PGSS drying process requires high GLR (gas/liquid ratio) in order to extract as much water as possible. The amount of water extracted inside the static mixer is related to the evaporation duty of the spray tower and is governed by the pre-expansion temperature and pre-expansion pressure which must be carefully adjusted. Higher pre-expansion pressure will increase the flow-rate of $\mathrm{SC}-\mathrm{CO}_{2}$ which will improve conditions for water removal inside static mixer. On the other hand higher pressure difference will decrease the temperature inside spraying tower due to the bigger Joule-Thompson effect what will result in water condensation inside spraying tower as in case of strawberry concentrate. Too low pressure will reduce extraction conditions in the static mixer and consequently decrease evaporation duty of the spray tower and thus no dry powder will be obtained as in case of blueberry concentrate.

\section{2. Physical Properties}

\section{2. 1. Water Content}

Amount of water content in the final fruit powders can be used for predicting their stability during storage. Analysis of the final powders processed by different drying techniques show that the final moisture content for all powdered fruits was below 3\%. Additionally, water activity level in all fruit powders was in-between $0,12-0,25$
(Table 6). Both results indicates that relatively dry and microbiological stable powders can be obtained by all applied methods since growth of microorganisms responsible food spoilage is inhibited at water activity levels below $0,6^{22}$ Comparable observations were made by Horszwald et. al., ${ }^{23}$ Bhusari et. al. ${ }^{24}$ and Fazaeli et. al $^{25}$ who worked on drying of aronia juice, tamarind pulp and black mulberry juice using different drying techniques such as spray drying, freeze drying and vacuum drying.

Table 7. - Water content measurements

\begin{tabular}{|c|c|c|c|}
\hline & $\begin{array}{c}\text { Water activity } \\
\text { activity } \\
\mathbf{a}_{\mathbf{w}}\end{array}$ & $\begin{array}{c}\mathrm{W}_{\mathrm{H}_{20}} \\
{\left[\mathrm{~g} \mathrm{H}_{2} \mathrm{O} /\right.} \\
100 \text { g sample] }\end{array}$ & $\begin{array}{c}\mathrm{W}_{\mathrm{MD}} \\
{[\mathrm{g} / 100 \mathrm{~g}} \\
\text { dry matter }]\end{array}$ \\
\hline Banana PGSS & 0,19 & 2,88 & 0 \\
\hline Banana FD & 0,12 & 1,05 & 0 \\
\hline Banana SD & 0,22 & 2,03 & 68 \\
\hline Blueberry VD & 0,17 & 0,75 & 20 \\
\hline Blueberry L-FD & 0,16 & 2,34 & 20 \\
\hline Blueberry SD & 0,25 & 2,5 & 60 \\
\hline Strawberry L-FD & 0,22 & 2,0 & 20 \\
\hline Strawberry SD & 0,20 & 2,15 & 68 \\
\hline
\end{tabular}

\section{2. 2. Total Colour Difference}

Results of total colour difference show the effect of the different maltodextrin concentrations and drying temperature on the colour characteristics of the final products (Table 7-8). Lightness value $\left(\Delta L^{*}\right)$ indicates that the colour is affected by the maltodextrin concentration while processing temperature is affecting the hue of red $\left(\Delta a^{*}\right)$ and yellow $\left(\Delta b^{*}\right)$ colour. An increase in lightness was observed with increasing maltodextrin concentration in all fruit powders. This can be explained with the inherited colour of maltodextrin. Comparing differences in hue values for banana powders decrease of yellow hue was observed while difference in red hue was smaller. When comparing blueberry and strawberry powders an increase of red hue was observed within fruit powders processed with spray drying while smaller difference in yellow hue was observed. This observation indicates that processing temperatu-

Table 8. - Hunter colour values measurements

\begin{tabular}{lccrr}
\hline Samples & $\begin{array}{c}\mathbf{W}_{\text {MD }} \\
{[\mathbf{g} / \mathbf{1 0 0 g}} \\
\mathbf{d r y} \text { matter }]\end{array}$ & $\mathbf{L}^{*}$ & $\mathbf{a}^{*}$ & $\mathbf{b}^{*}$ \\
\hline Banana PGSS & 0 & 73,0 & 3,7 & 28,4 \\
Banana FD & 0 & 73,2 & 3,5 & 28,3 \\
Banana SD & 68 & 88,8 & 0,4 & 12,2 \\
Blueberry VD & 20 & 22,1 & 15,7 & 1,3 \\
Blueberry L-FD & 20 & 19,7 & 15,7 & 2,6 \\
Blueberry SD & 60 & 47,3 & 33,8 & $-3,9$ \\
Strawberry L-FD & 20 & 41,7 & 17,5 & 11,0 \\
Strawberry SD & 68 & 53,8 & 22,8 & 6,4 \\
\hline
\end{tabular}


re is affecting the colour of final fruit powder. ${ }^{26}$ Similar observation was made by Yemmireddy et. al with blueberries using different drying methods such as air dryer, fluidized bed dryer and air-impingement. ${ }^{27}$

Results of total colour difference show the effect of the different maltodextrin concentrations and drying temperature on the colour characteristics of the final products. Lightness value $\left(\Delta L^{*}\right)$ indicates that the colour is affected by the maltodextrin concentration while processing temperature is affecting the hue of red $\left(\Delta a^{*}\right)$ and yellow $\left(\Delta b^{*}\right)$ colour. An increase in lightness was observed with increasing maltodextrin concentration in the final powdered product.

Table 9. - Total colour difference calculations

\begin{tabular}{lcccc}
\hline Sample & $\boldsymbol{L}_{\mathbf{0}}^{*}-\boldsymbol{L}^{*}$ & $\boldsymbol{a}_{\mathbf{0}}^{*}-\boldsymbol{a}^{*}$ & $\boldsymbol{b}_{\mathbf{0}}^{*}-\boldsymbol{b}^{*}$ & $\boldsymbol{\Delta} \mathbf{E}$ \\
\hline Banana SD vs. PGSS & 15,8 & $-3,2$ & $-16,2$ & 23 \\
Banana SD vs. FD & 15,6 & $-3,1$ & $-16,1$ & 22 \\
Blueberry SD vs. L-FD & 27,5 & 18,2 & $-6,5$ & 33 \\
Blueberry SD vs. VD & 25,2 & 18,1 & $-5,2$ & 31 \\
Strawberry SD vs. L-FD & 12,2 & 5,3 & $-4,5$ & 13 \\
\hline
\end{tabular}

\section{2. 3. Antioxidant Activity}

Increase of antioxidant activity was observed with decreasing processing temperature. Results can be correlated to the total colour change when comparing blueberry powders. Blueberry powders processed with freeze drying or vacuum drying had higher value of antioxidants comparing to blueberry powder obtained by spray drying (Table 9). Both antioxidant activity and colour change was found to be inversely proportional to the processing temperature. Decrease in antioxidant activity can be explained by thermal decomposition of heat-sensitive compounds. ${ }^{28}$ However, in case of strawberry no correlation was found between processing temperature and antioxidant activity (Table 9). Comparable observation with blueberry extract was observed by Flores et. al. ${ }^{29}$ Furthermore decrease in antioxidant activity with increased processing temperature was observed as well with apple, pear, mango and papaya when exposed to different drying procedures. ${ }^{30}$ Higher retention of antioxidants with de- creased process temperature was found as well when comparing sun drying, oven drying, vacuum drying and freeze drying method of tomatoes and ginger by Gümüşay et. al. ${ }^{31}$

Table 10. - Antioxidant activity

\begin{tabular}{lcc}
\hline Sample & \multicolumn{2}{c}{ Antioxidant capacity } \\
& $\begin{array}{c}\mathbf{A O}_{\text {Actual }} \\
{\left[\mathbf{m g} / \mathbf{g}_{\text {sample }}\right]}\end{array}$ & $\begin{array}{r}\mathbf{A O}_{\text {Actual }} \\
{\left[\mathbf{m g} / \mathbf{g}_{\text {fruits }}\right]}\end{array}$ \\
\hline Blueberry L-FD (20\% MD) & 27,7 & 34,6 \\
Blueberry VD (20\% MD) & 20,2 & 25,2 \\
Blueberry SD (60\% MD) & 9,8 & 24,6 \\
Strawberry SD (68\% MD) & 8,7 & 27,3 \\
Strawberry L-FD (20\% MD) & 2,3 & 2,8 \\
\hline
\end{tabular}

\section{3. Sensory Evaluation}

\section{3. 1. Ranking Method}

Sensory evaluation of reconstituted fruit powders revealed that both key attributes intensity and overall flavour profile were influenced, as expected, by drying parameters. Friedman's test results $\left(\mathrm{F}_{0}<\mathrm{F}\right)$ for blueberry fruit powders indicate that panellist did perceive differences between samples with a risk of $\alpha \leq 5 \%$ (type I error). Among blueberry samples spray dried samples was recognized as the least intense and typical what can be correlated to process parameters. During spray drying raw materials are exposed to higher operating temperature comparing to liquid freeze drying and vacuum drying what results in higher loss of flavouring compounds and consequently decrease of intensity and/or in change of flavouring profile. For each key attribute we can divide samples in two different categories. Regarding flavour intensity we can conclude that the sample obtained by spray drying was statistically significant different from samples processed by liquid-freeze drying and vacuum drying technique, while there was no statistically significant difference noticed between liquid-freeze dried and vacuum dried fruit powders. On the other hand it was found that blueberry powder processed by liquid freeze drying was significantly different regarding typicality. Vacuum dried and

Table 11. - Sensory evaluation for blueberry fruit powders

\begin{tabular}{|c|c|c|c|c|c|c|c|c|}
\hline & Mean & $\mathbf{P}$ & $\sum$ & $\begin{array}{c}\mathbf{F} \\
\text { Observed }\end{array}$ & $\begin{array}{c}\mathbf{F}_{0} \\
\text { Critical } \\
\alpha=\mathbf{0 , 0 5}\end{array}$ & $\begin{array}{c}\text { LSD } \\
\alpha=\mathbf{0 , 0 5}\end{array}$ & $\begin{array}{c}\mathrm{L} \\
\text { Observed } \\
\alpha=\mathbf{0 , 0 5}\end{array}$ & $\begin{array}{c}\mathbf{L}_{0} \\
\text { Critical } \\
\alpha=\mathbf{0 , 0 5}\end{array}$ \\
\hline \multicolumn{9}{|c|}{ Intensity } \\
\hline L-FD & 2,43 & 14 & 34 & 15,43 & 6,143 & 10,37 & 186 & 178 \\
\hline VD & 2,29 & 14 & 34 & & & & & \\
\hline SD & 1,14 & 14 & 16 & & & & & \\
\hline \multicolumn{9}{|c|}{ Typicality } \\
\hline L-FD & 2,71 & 14 & 38 & 13 & 6,143 & 10,37 & 187 & 178 \\
\hline VD & 1,93 & 14 & 27 & & & & & \\
\hline SD & 1,36 & 14 & 19 & & & & & \\
\hline
\end{tabular}

Feguš et al.: Effect of Drying Parameters on Physiochemical ... 
Table 12. - Sensory evaluation for banana fruit powders

\begin{tabular}{|c|c|c|c|c|c|c|c|c|}
\hline & \multirow[t]{2}{*}{ Mean } & \multirow[t]{2}{*}{$\mathbf{P}$} & \multirow[t]{2}{*}{$\sum$} & \multicolumn{2}{|c|}{$\mathbf{F}_{\text {test }}$} & \multirow{2}{*}{$\begin{array}{c}\text { LSD } \\
\alpha=0,05\end{array}$} & \multicolumn{2}{|c|}{$\mathbf{L}$} \\
\hline & & & & Observed & $\begin{array}{l}\text { Critical } \\
\alpha=0,05\end{array}$ & & $\begin{array}{c}\text { Observed } \\
\alpha=0,05\end{array}$ & $\begin{array}{l}\text { Critical } \\
\alpha=0,05\end{array}$ \\
\hline \multicolumn{9}{|c|}{ Intensity } \\
\hline PGSS & 2,43 & 14 & 34 & 10,85 & 6,143 & 10,37 & 182 & 178 \\
\hline FD & 2,29 & 14 & 32 & & & & & \\
\hline SD & 1,29 & 14 & 18 & & & & & \\
\hline \multicolumn{9}{|c|}{ Typicality } \\
\hline PGSS & 2,21 & 14 & 31 & 7,00 & 6,143 & 10,37 & 181 & 178 \\
\hline FD & 2,36 & 14 & 33 & & & & & \\
\hline SD & 1,43 & 14 & 20 & & & & & \\
\hline
\end{tabular}

Table 13. - Sensory evaluation for strawberry fruit powders

\begin{tabular}{lllllllll}
\hline & $\mathbf{P}$ & $\mathbf{X}$ & $\mathbf{P}_{\mathbf{0}}$ & $\mathbf{P}_{(\mathbf{d})}$ & $\mathbf{P}_{\mathbf{A}}$ & $\boldsymbol{\alpha}$ & $\boldsymbol{\beta}$ & $\mathbf{1 - \beta}$ \\
\hline $\begin{array}{l}\text { L-FD } \\
\text { SD }\end{array}$ & 14 & 12 & 0,33 & 0,25 & 0,5 & 0,0001 & 0,9935 & 0,0065 \\
\hline
\end{tabular}

spray dried fruit powders were not recognized as significantly different. Additionally, Page test confirmed the assumption that samples processed under milder process parameters, in our case liquid freeze drying followed by vacuum drying, should be recognized as more intensive and more typical due to the lower operating temperature and better retention of flavouring compounds $\left(\mathrm{L}_{0}<\mathrm{L}\right)$. Results are presented in Table 10.

Similar results were obtained in case of banana powders. Regarding intensity it was found out that the fruit powder processed by PGSS drying method was the most intense, while freeze dried banana powder was most typical. For both key attributes there was no statistically significant difference confirmed between fruit powders obtained by PGSS drying and freeze drying technique, while spray dried sample was found as statistically significantly different from others. Page test identified differences between samples according to assumption that milder operating conditions will result in better sensory characteristics of the final product. Results are presented in Table 11.

\section{3. 2. Triangle Test}

A total of 12 assessors out of 14 correctly identified the odd sample. Obtained result (Table 12) confirms that strawberry fruit powders processed by spray drying and liquid freeze drying were perceived as statistically different at $5 \%$ significance level.

\section{Conclusion}

Relatively dry fruit powders without carrier material were successfully processed. The results obtained from the experimental work indicate that it is possible to produce fruits powders without or with minimal addition of maltodextrin using fruit purees and concentrates as raw materials by alternative drying methods. However, it was observed that fruit powders without maltodextrin exhibit very sticky behaviour due to the high concentration of sugar and thus proper handling of the final product was required. The increase of stickiness was observed with decreasing concentration of maltodextrin. Evaluation of processed powders led us to an observation that physiochemical characteristics (colour retention and antioxidant activity) are in correlation with processing temperature. Higher degree of exposure to elevated temperature leads to lower preservation of colour and antioxidant activity. Similar results were obtained with flavour retention properties. Sensory panel perceived differences between different samples and in general the lowest ranking numbers were assigned to fruit powders process by spray drying technique.

\section{References}

1. H. G. Kessler, Food and Bio process engineering - Dairy Technolohy, 5th Edition, Publishing House A. Kessler, 1998, 256-269.

2. J. M. Jay, M. J. Loessner, D. A. Golden, Modern Food Microbilogy, 7th Edition, Springer, 2005, 41-45.

3. M. W. Woo, A.S. Mujumdar, W. R. W. Daud, Spray Drying Technology, 2010, 1, 114-115.

4. G. V. Barbosa-Canovas, Food powders: Physical Properties, Processing, and Functionality, Kluwer Academic/Plenum Publishers, 2005, 271-299.

5. S. V. Jangam, C. L. Law, A. S. Mujumdar, Drying of Foods, Vegetables and Fruits, 2011, 2, 3-5. 
6. J. G. Brennan, Food Processing Handbook, Wiley-VCH, 2006, 105-110. http://dx.doi.org/10.1002/3527607579

7. A. Gharsallaou, G. Roudaut, O. Chambin, A. Voilley, R. Saurel, Applications of spray-drying in microencapsulation of food ingredients: An overview, Food Research International, 2007, 40, 1107-1121. http://dx.doi.org/10.1016/j.foodres.2007.07.004

8. K. Dhanalaskshmi, S. Ghosal, S. Bhattacharya, Agglomeration of Food Powder and Applications; Critical Reviews in Food Science and Nutrition, 2011, 51, 432-441. http://dx.doi.org/10.1080/10408391003646270

9. V. Truong, B. R. Bhandari, T. Howes, Optimization of cocurrent spray drying process of sugar rich foods: Part I-Moisture and glass transition temperature profile during drying, Journal of Food Engineering, 2005, 71, 55-65. http://dx.doi.org/10.1016/j.jfoodeng.2004.10.017

10. R. W. Hartel; Crystallization in Foods; AN Aspen Publications, 2001, 130-139.

11. A. M. Goula, T. D. Karapantsios, D. S. Achilias, K. G. Adamopoulos, Water sorption isotherms and glass transition temperature of spray dried tomato pulp, Journal of Food Engineering, 2008, 85, 873-883. http://dx.doi.org/10.1016/j.jfoodeng.2007.07.015

12. C. Hammam, F. René; Determination of Freeze-drying Process Variables for Strawberries, Journal of Food Engineering, 1997, 32, 133-154. http://dx.doi.org/10.1016/S0260-8774(97)00023-X

13. E. Weidner, M. Petermann, Z. Knez, Multifunctional composites by high-pressure spray processes; Current Opinion in Solid State and Materials Science, 2003, 7, 385-390. http://dx.doi.org/10.1016/j.cossms.2003.09.002

14. Z. Knez, E. Weidner; Particles formation and particle design using supercritical fluids, Current Opinion in Solid State and Materials Science, 2003, 7, 353-361. http://dx.doi.org/10.1016/j.cossms.2003.11.002

15. Á.l Martín, E. Weidner, PGSS-drying: Mechanisms and modeling, Journal of Supercritical Fluids, 2010, 55, 271-281. http://dx.doi.org/10.1016/j.supflu.2010.08.008

16. D. Meterc, M. Petermann, E. Weidner, Drying of aqueous green tea extracts using a supercritical fluid spray process, Journal of Supercritical Fluids, 2008, 45, 253-259. http://dx.doi.org/10.1016/j.supflu.2008.02.001

17. E. Besco, E. Braccioli, S. Vertuani, P. Ziosi, F. Brazzo, R. Bruni, G. Sacchetti, S. Manfredini; The use of photochemiluminescence for the measurement of the integral antioxidant capacity of baobab products, Food Chemistry, 2007, 102, 1352-1356. http://dx.doi.org/10.1016/j.foodchem.2006.05.067

18. O. A. Caparino, J. Tang, C. I . Nindo, S. S. Sablani, J. R Powers, J. K. Fellman, Effect of drying methods on the physical properties and microstructure of mango (Philippine ' $\mathrm{Ca}-$ rabo' ver.) powder, Journal of Food Chemistry, 2012, 111, 125-148.
19. Z. Fang, B. Bhandari, Comparing the efficiency of protein and maltodextrin on spray drying of bayberry juice, Food research International, 2012, 48, 478-483.

http://dx.doi.org/10.1016/j.foodres.2012.05.025

20. B. Adhikari, T. Howes, B. R. Bhandari, V. Troung, Effect of addition of maltodextrin on drying kinetics and stickiness of sugar-rich and acid-rich foods during convective drying: experiments and modelling, Journal of Food Engineering, 2004, 62, 53-68. http://dx.doi.org/10.1016/S0260-8774(03)00171-7

21. L.H. Mosquera, G. Moraga, N. Martinez-Navarrette, Effect of maltodextrin on the stability of freeze dried borojo (Borojoa patinoi Cuatrec.) powder, Journal of Food Engineering, 2010, 97, 72-78. http://dx.doi.org/10.1016/j.jfoodeng.2009.09.017

22. B. Ray, Fundamental food microbiology 3rd edition, Taylor\& Francis, 2005, 72-73.

23. A. Horszwald, H. Julien, W. Andlauer, Characterisation of Aronia powders obtained by different drying process, Food Chemistry, 2013, 141, 2858-2863.

http://dx.doi.org/10.1016/j.foodchem.2013.05.103

24. S. N. Bhusari, Khalid Muzaffar, Pradyuman Kumar, Effect of carrier agents on physical and microstructural properties of spray dried tamarind pulp powder, Powder Technology, 2014, 266, 354-364. http://dx.doi.org/10.1016/j.powtec.2014.06.038

25. M. Fazaeli, Z. Emam-Djomeh, A. K.i Ashtari, M. Omid, Effect of spray drying conditions and feed composition on the physical properties of black mulberry juice powder, food and bioproducts processing, 2012, 90, 667-675.

26. H.D. Belitz, W. Grosch, P. Schieberle, Food Chemistry 4th edition, Springer-Verlag, 2009, 849-856.

27. V. K. Yemmireddy, M. S. Chinnan, W. L. Kerr, Y. Hung, Effect of drying method on drying time and physico-chemical properties of dried rabbiteye blueberries, Food Science and Technology, 2013, 50, 739-745. http://dx.doi.org/10.1016/j.lwt.2012.07.011

28. E. A. Decker, R. J. Elias, D. J. McClements, Oxidation in foods and beverages and antioxidant applications Vol.1, Woodhead publishing, 2010, 384-385. http://dx.doi.org/10.1533/9780857090331

29. F. P. Flores, R. K. Singh, W. L. Kerr, D. R. Phillips, F. Kong, In vitro release properties of encapsulated blueberry (Vaccinium ashei) extracts, Food Chemistry, 2015, 168, 225-232. http://dx.doi.org/10.1016/j.foodchem.2014.07.059

30. C. H. Chong, C. L. Law, A. Figiel, A. Wojdyło, M. Oziembłowski, Colour, phenolic content and antioxidant capacity of some fruits, Food Chemistry, 2013, 141, 3889-3896. http://dx.doi.org/10.1016/j.foodchem.2013.06.042

31. Ö. A. Gümüsay, A. A. Borazan, N. Ercal, O. Demirkol, Drying effects on the antioxidant properties of tomatoes and ginger, Food Chemistry, 2015,173, 156-162. http://dx.doi.org/10.1016/j.foodchem.2014.09.162 


\section{Povzetek}

Raziskovalno delo je zajemalo proučitev možnosti upraševanja sadnih pripravkov brez uporabe sušilnih sredstev ter raziskati vpliv procesne temperature na kvaliteto uprašenih sadnih pripravkov. Sadne pripravke (bananin in jagodni pire ter koncentrat borovnice) smo procesirali z uporabo vakuumskega sušenja pri temperaturi $-27-17^{\circ} \mathrm{C}$, sušenja $\mathrm{z}$ razprševanjem pri temperaturi $130-16^{\circ} \mathrm{C}$ ter $\mathrm{z}$ uporabo postopka za pridobivanje delcev iz raztopin nasičenih $\mathrm{s}$ plinom $\mathrm{v}$ temperaturnem območju $112-152{ }^{\circ} \mathrm{C}$. Dobljenim praškastim produktom smo določili vsebnost vode, razliko v barvi ter vsebnost antioksidantov. Ugotovili smo, da je s predlaganimi postopki možno pripraviti sadje v prahu brez oziroma z minimalnim dodatkom maltodekstrina. Dodatno smo opazili, da temperatura procesiranja vpliva na kvaliteto končnega produkta in sicer višja temperatura negativno vpliva na obstojnost barve, antioksidativih lastnosti ter organoleptičnih značilnosti sadnih pripravkov. 
